\title{
The Role of Language Laboratory in English Language Learning Settings
}

\author{
Abdelaziz Mohammed ${ }^{1}$ \\ ${ }^{1}$ College of Sciences \& Arts-Qilwah, Albaha University, Saudi Arabia \\ Correspondence: Abdelaziz Mohammed, College of Sciences \& Arts-Qilwah, Albaha University, Saudi Arabia. \\ Tel: 966-507-822-489. E-mail: zizo_moh22@yahoo.com
}

Received: December 5, 2016 Accepted: January 10, 2017 Online Published: January 12, 2017

doi: 10.5539/elt.v10n2p86 URL: http://dx.doi.org/10.5539/elt.v10n2p86

\begin{abstract}
This study aims at determining the relationship between language labs and the effective ways of mastering better performance of English language. The study raised two questions. They are "Is language laboratory useful in teaching English to Saudi students?" And "How do language labs help in improving students' performance?" Descriptive and analytical approaches have been adopted in this study. Two subject groups representing different situations are selected for investigation. Each group contained 27 students from fourth level who are studying English as their major. The instruments used were tests of all English components to draw significant findings. Generally, the findings proved that using effective language laboratories in teaching English is essential in teaching listening and mastering better features of speaking. In addition, the study recommends that the using of language labs in the teaching of English is highly needed in colleges.
\end{abstract}

Keywords: applied Linguistics, ELT, Language and technology, language labs

\section{Introduction}

\subsection{Statement of the Problem}

In Saudi Arabia, at almost all educational institutes, English language is being taught from fourth grade primary level. Although students of the English Department at College of Sciences \& Arts in Qlwah in Albaha University have been studying English as Foreign Language (EFL) for more than ten years, their English proficiency is very weak especially in communication aspects (listening and speaking skills). This problem, somehow, is due to the little practice they performed during their lessons; even though the curriculum is very rich of theses components. Thus, it is assumed that students need intensive activities to attract they practice listening and speaking in and out of their classes (Slobin, 1985, p. 1164). He adds that the only linguistic materials that can figure in language production are stretches of speech that attract the child's attention to a sufficient degree to be noticed and held in memory. Then the importance of language labs can solve this problem and make English learning process is very attractive for both teachers and students. Researches about Saudi context concerning the relationship between learning English language and language lab is neglected. During the updating digital ages, whether we like it or not, people are connected regardless of the location. Innovation in technology has accurately brought the world into our homes in the form of TV, smart phones or internet. As people are not living in an isolated planet, technological devices allow them to watch events happening everywhere and talk to people living in English speaking countries via social media. As a result, we are experiencing different languages, cultures and traditions worldwide. During the ages, English language learning was enforced naturally to the use of media. However, language lab can greatly help students to learn a language of their own choices and pace. Previously, the language laboratory appeared as an audio or audiovisual used as equipment in language teaching. They can be used in schools, universities, and all academies. So, this study is going to answer these two questions:

1) Is language laboratory useful in teaching English to Saudi students?

2) How do language labs help in improving students' performance?

Thus, the study assumes that "Using language lab in English learning settings will probably improve students mastering of EFL." And "Using language lab in English learning settings will help Saudi students mastering listening and speaking skills." 


\section{Literature Review}

\subsection{Historical Background}

English-language educators have been aggressively involved in the use of audio equipment. Earlier, Buchanan and MacPhee (1928), Bagster-Collins, (1930) state that from 1893, there were commercial record sets available in Spanish and English as a foreign language, but phonograph was only used in regular classes and for self-study at home. Later, it started by teaching of mathematics, science, and foreign languages in America's schools by 1958, but Derthick (1959) has described foreign language. The history of the language laboratory as has written by Parker (1961), Diekhoff (1965), and Hocking (1967), had first launched in 1957 and then in 1958 by the military organizations. Later, (Léon, 1962; Peterson, 1974; \& Saettler, 1990, p. 187) state that the first lab was established at the University of Grenoble in 1908. Delcolque, et al, (2000) adds that the first audio device welcomed is the phonograph, and have immediately adopted other advances in audio technology such as magnetic tape and digital media

No doubt, the 1960s era was the golden period of the language laboratory that led to an explosion in the number of facilities. According to Hocking (1967), by 1962, there was a massive increase in the number of labs at the secondary level since 1958. Most of these were in medium-to-large school districts (Godfrey, 1967). Within and after 1962, there were more than 900 labs in higher education (Hocking, 1967). Additionally, more post secondary labs were built from 1965 when matching funds became available (Ek, 1974, pp. 17-23). Although they did not cite a source for their information, Keck and Smith $(1972$, p. 5) claim that by mid-decade, an estimated 10,000 language laboratories had been installed in secondary schools and 4,000 more could be found in institutions of higher learning". Finally, Parker (1960, pp. v-viii) wrote about the motivation for language laboratory in conferences. He stated that foreign language teachers feel themselves suddenly involved in a technological revolution, suddenly chin-deep in a tide of new demands upon their competencies, and they seek, some almost frantically, enlightenment and practical help.

Many scholars provide a clear and strong link between the educational technology field, the programmed instruction movement and the foreign language profession. Cornfield (1966, p. VI) acknowledges all the inspiration, philosophy, and ideas given her to Dale. Other books by Carroll (1962), Marty (1962, pp. 52-53), and the pedagogy textbook of Grittner (1969) provide further evidence of the favor of programmed instruction by foreign language educators who were also interested in the language laboratory mainly the technical development of audio cassette (Dodge, 1968, pp. 331-335). Aikens and Ross (1977, pp. 40-46) state that the ability to use a tape would help students struggling with a difficult passage.

Software systems can be easily installed onto a PC based network, making them both multi locations and much more feature rich in how and what media they can manage. This can be impeded by using the course materials constructed in the targeted course (especially English Language listening \& speaking). These days all networks are able to work with software on language lab solutions and deliver media synchronously. This function can be beneficiary for using between university campuses to deliver administration talks to staff members as well as for students and other audience in/outside the campuses. Moreover, as there is no direct contact between professors and their female students to control their participation, attendance, or language proficiency, these technical items (mainly English labs) are considered to be more beneficial in Saudi context.

The content that can be used in the new language labs are not just audio, but video, flash-based materials, internet, etc. Moreover, they are much more engaging for both teacher and student and much quicker in speed and variety of the delivery of media from teacher to student, student to teacher or student to student.

Furthermore, developments in language labs are now apparent as access moves from a fixed network and related Microsoft operating systems to the online and browsers. Students can now access and work from these new cloud labs from their own devices at anytime and anywhere. Students can interrogate, record audio and video files; and be marked and assessed by their teachers remotely.

\subsection{Types and Importance of Language Labs}

In addition to what's mentioned in the introduction, to make sure that students are paying attention to all aspects of phonetics such as pronunciation, accents etc., could record and assess their performance. Hmoud, (2014, pp. 84-94) reveals that the language lab provides access to native-speakers to enhance students learning correctly. To pursue higher studies abroad, language lab would help students in studying the language of the country where they are planning to complete their higher education (i.e. EFL students are required to pass TOEFL/IELTS if they plan to study in some of the English speaking countries). Meanwhile, it is important that the layout of the lab is encouraging for effective communication and monitoring of the learners. As high acquiring of communication 
skills are essential in almost all fields of careers, language lab can help in gaining this important skill.

\subsection{The Configuration and Appearance of labs}

Generally, the traditional system includes a keyboard that is wired to a number of rows of student compartments, sometimes as ' $U$ ' shape carrels, containing a student tape recorder and headset with a boom arm microphone (see the photo below). Moreover, the teacher console (keyboard) is usually fitted with a tape recorder to monitoring each compartment in the class by the teacher headset and an intercom facility to enable 2-way communication between the teacher and his/her students individually.

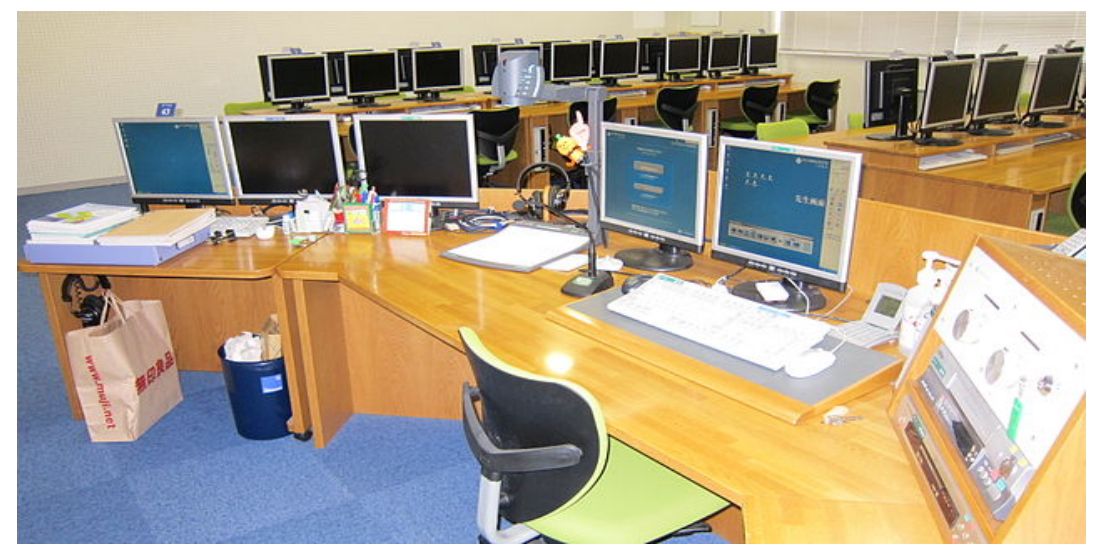

Figure 1. A Japanese high school language lab shows students' positions

First generation laboratories or the simplest ones allow the teacher to control the tape of the student booths (record, stop, rewind etc.) from the monitor desk. This feature allows easy distribution of the master program material, which is often copied at high speed onto the student positions for later use by the students at any time.

As in the photo below, better tape laboratories hold the tape machine behind a protective plate, leaving only a control panel accessible to the students or lock the cassette door. This keeps the expensive and sensitive decks free from student misuse and dust.

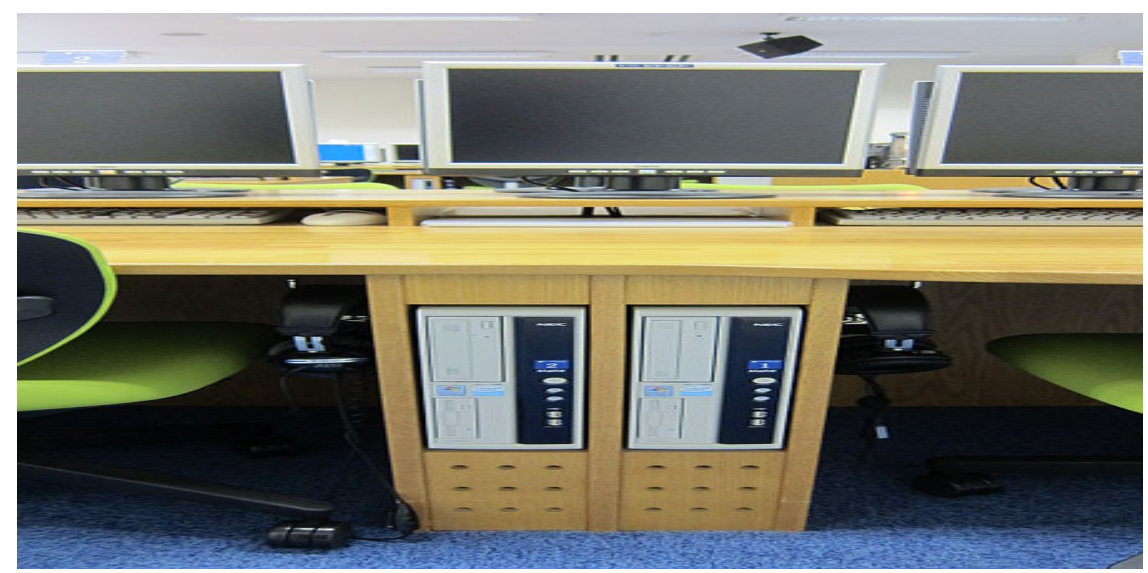

Figure 2. Teacher's control (Keyboard)

\subsection{Operating the Audio Active-comparative System}

The teacher can hand over control of the decks to the students at the time that the master program is being transferred onto the student recorders. Moreover, the student would simultaneously hear the playback - when pressing the keyboard - of the program whilst being able to record his or her own voice in the pauses using the microphone. Technologically, this overdubbing was made possible by the use of a two-channel tape recorder 


\subsection{Digital Language Laboratories}

Still the principle of language laboratories essentially has not changed. They remain a teacher-controlled system connected to a number of student booths, containing a student's control mechanism and a headset with a microphone. Digital language labs have the same principle. A software of language lab changes the concept of where and what a language lab is. Software can be installed on any networked PCs anywhere on a school, college or university campus. Software systems can be located in one room, from room-to-room or campus-to-campus. The term language lab is no longer favored by recent generation. However, new terms like 'language media center' or 'learning resource center' attempt to replace the term 'language lab' meanwhile they can hold the new goals and new technologies (Scinicariello, 1997; 185-213). Scinicariello, (1997; 185-213) reveals that whatever they be called there is no ideal language lab for the twenty-first century. Recently, Lundi (2010) states that language labs are adequate places where a learner can undergo self learning experience at his own pace, by practicing a host of exercises through technology. These exercises can be done in all the four modalities of language learning.

\subsection{Functionality of Language Labs}

All current language labs will have a level of teacher control to manage student desktops or any other networked devices. These levels of functionality of labs vary from manufacturer to manufacturer. The more sophisticated software labs have a higher level of teacher management and control over the student desktop the more they will be needed. One of the key differences in the high-end software products is their ability to work live with the students as they record and work with media (Roby, 2004, pp. 523-541). Therefore, instead of waiting to correct student recordings after they have been recorded and collected back it is now possible for a teacher to work synchronously and live with students on their own, in pairs or in groups, thus enhancing the immediacy of the teaching and learning experience (direct interactions).

\section{Method}

In this paper, the method used for data collection is the descriptive and analytical approach. Literature written about the role of language labs in English Language learning Settings was collected. The samples (27 students) of the study were chosen randomly from students of fourth level in the English department at the College of Sciences \& Arts in Qilwah, Albaha University, Saudi Arabia. The study took place during the first term of the academic year 2015-2016. The students were involved in a communicative competence method. They were taught ( 2 hours weekly) the course content of the fourth level. Because of the lack of the language labs in the university, only computer system and headphones were used to teach the English components. The most interesting is that it should be stressed that none of the subjects had previous laboratory experience. The students had taken the pretest before the course started. At the end of the term, they had taken the post-test (listening, speaking, reading, writing, grammar and vocabulary components). Both pre and post-test questions were administered and modified by the researcher after had been judged by his colleagues in and out of Albaha University. Two types of laboratory equipments were used. They were audio-active and recording-playback. The first was a headset with earphones and a microphone; the second was an identical headset plus a tape recorder for each student. Here in this study, these types of equipments were not like modern language labs. They were connected to desktop computers that only available in the college.

\section{Results}

To precisely calculate and analyze the results obtained by the subjects in both pre and post-tests, descriptive statistics were used and ANOVA correlation was computed. Concurrently, ANOVA (two-factor without replication) proved that, the difference in the scored marks of the pretest was significant (T-stat $=2.731$; P-value $=$ 0.0421 , and $\mathrm{T}$-crit $=2.603$ ), i.e. the student was significantly varied in their distribution in scoring $5,4,3,2,1$ and 0 (see table 1 below).

Table 1. ANOVA two-factor without replication

\begin{tabular}{|c|c|c|c|c|}
\hline & T-stat* & $P$-value** & T-crit ${ }^{* * * *}$ & Difference \\
\hline Rows (marks) & 2.731071 & 0.042141 & 2.602987 & Significant \\
\hline Columns (tests) & 0.938871 & 0.47312 & 2.602987 & Not significant \\
\hline
\end{tabular}

${ }^{*} T$-Stat $=$ the value calculated from the available data. $\quad * *$-value $=$ probability for sensitivity.

$* * * T$-Crit $=$ the critical value. 
As seen above, ANOVA also proved that the difference in the column level (tests) was not significant (T-stat= 0.938 , P-value $=0.473$, and T-crit $=2.603$ ), i.e. the students' performance in all tests was similar and the concept that, the students had a better performance in one test in comparison to other tests can be ignored.

Table 2. The Correlation between pretest components

\begin{tabular}{llllll}
\hline & Listening & Speaking & Reading & Writing & Grammar \\
\hline Speaking & 0.235 & 1 & & & \\
Reading & 0.759 & 0.532 & 1 & & \\
Writing & 0.503 & 0.565 & 0.763 & 1 & \\
Grammar & 0.514 & 0.495 & $\mathbf{0 . 9 9 0}$ & $\mathbf{0 . 9 0 0}$ & 1 \\
Vocabulary & 0.679 & 0.472 & $\mathbf{0 . 9 7 9}$ & $\mathbf{0 . 9 0 6}$ & $\mathbf{0 . 9 8 2}$ \\
\hline
\end{tabular}

Moreover, (as in Table 2 above) the correlation test proves that there was a high significant correlation ( 0.99$)$ between grammar and reading tests (i.e. $99 \%$ of the students who score a mark whatever it was in the grammar test, they score more or less the same mark in the reading test). Another great correlation $(0.98)$ can be detected between vocabulary and reading as well as between vocabulary and grammar (0.98), whereas a relative considerable correlation $(0.91)$ was also noticed between vocabulary and writing nearly as that between the grammar and writing (0.90). Moderate correlation was observed between writing and reading $(0.76)$ as well as that between reading and listening. While that between vocabulary and listening is $(0.68)$, grammar and listening is $(0.51)$ and writing and speaking is $(0.57)$. The correlation analysis also proves that, there was a very poor correlation between speaking and listening $(0.24)$.

It is clearly seen that high frequencies of students who score 4 out of 5 in all pretest sections are more than the frequencies of the other marks (Appendix 1). Although 8 students out of 27 obtain the full marks in the grammar test, students have high performance in the listening test $(96.26 \%$ passed $)$, followed by grammar $(92.59 \%$ passed), and then vocabulary ( $88.89 \%$ passed), proceeding writing and speaking $(85.18 \%$ passed) and lastly reading ( $81.48 \%$ passed). Accordingly, high frequency of fail was seen in grammar test $(14.82 \%$ failed), although 5 students scored zero in the reading test, while low frequency of fail students was observed in listening test (only $3.74 \%$ failed) in which only one student gets zero.

Table 3. ANOVA: Two-Factor without replication

\begin{tabular}{lllll}
\hline & T-stat* & P-value** & T-crit*** & Difference \\
\hline Rows (marks) & 41.64737 & $2.47 \mathrm{E}-11$ & 2.602987 & Significant \\
Columns (tests) & $-6.8 \mathrm{E}-15$ & \#NUM! & 2.602987 & Not significant \\
\hline$* T-S t a t=$ the value calculated from the available data. & $* * P$-value $=$ probability for sensitivity \\
$* * * T-C r i t=$ the critical value. & \multicolumn{2}{c}{ \#NUM!= very small number }
\end{tabular}

Table 4. The Frequencies of the post-test results

\begin{tabular}{llllll}
\hline & Listening & Speaking & Reading & Writing & Grammar \\
\hline Speaking & $\mathbf{0 . 9 6 7}$ & 1 & & & \\
Reading & 0.813 & 0.881 & 1 & & \\
Writing & $\mathbf{0 . 9 8 8}$ & $\mathbf{0 . 9 6 8}$ & 0.789 & 1 & \\
Grammar & $\mathbf{0 . 9 7 2}$ & $\mathbf{0 . 9 7 0}$ & $\mathbf{0 . 9 1 6}$ & $\mathbf{0 . 9 6 1}$ & 1 \\
Vocabulary & 0.864 & $\mathbf{0 . 9 1 4}$ & $\mathbf{0 . 9 9 4}$ & 0.843 & $\mathbf{0 . 9 4 9}$ \\
\hline
\end{tabular}

Moreover, as in Table 3 above, ANOVA (two-factor without replication) reflects that the difference in the scored marks of the post-test was significant $(\mathrm{T}$-stat $=41.64737$; P-value $=2.47 \mathrm{E}-11$; and $\mathrm{T}$-crit $=2.602987)$, i.e. the 
student was significantly vary in their distribution in scoring 5, 4, 3, 2, 1 and 0 . Moreover, ANOVA proved that the difference in the column level (tests) was not significant (T-stat $=-6.8 \mathrm{E}-15$; and T-crit $=2.602987$ ), i.e. the students' performance in all test components was similar which implies that the students had a better performance in one test when compared to other tests can be ignored. Concurrently, the correlation measurement of the test sections results proved that, there was a high correlation $(0.99)$ between vocabulary and reading as well as that between writing and listening tests (i.e. $99 \%$ of the students who score marks whatever it was in the writing test, they score more or less the same marks in the listening test). In addition, a great correlation (0.97) can be seen between grammar and listening (0.97), as well as that between grammar and speaking (0.97), as so between writing and speaking (0.97) and then what is between speaking and listening (0.97). Whereas a pretty high correlation (0.96) was also noticed between vocabulary and listening as well as that between grammar and writing (0.96) nearly as that between the vocabulary and grammar $(0.95)$. Another moderate correlation can be seen between grammar and reading $(0.92)$, nearly as that between vocabulary and speaking $(0.91)$. A reasonable correlation was observed between reading and speaking $(0.88)$, nearly as that between vocabulary and listening (0.86). A rational correlation (0.84) between vocabulary and writing was reflected and a moderate one $(0.81)$ between reading and listening was appeared. The correlation analysis also attested to the fact that, there was a reasonable correlation between writing and reading $(0.79)$.

\section{Discussion}

From the analysis above, it seems that there were no significant differences between the pretest components such as reading, vocabulary, and grammar tests; but the post-test was tested significantly higher than the pretest on the fluency of the speaking component. The students also scored significantly higher on the listening component in post-test. The results also showed that the students were significantly superior in listening skill, especially in the post-test. This result clearly approved the hypothesis of the study "Using language lab in English learning settings will probably improve students mastering of EFL." And "Using language lab in English learning settings will help Saudi students mastering listening and speaking skills." Thus, the null hypothesis was rejected. The difference between the post-test components was not significant, but between pretest was significantly is higher. From the above findings, one can draw a conclusion is that the use of a fully equipped lab daily with it altogether will probably affect students' performance especially in the listening and speaking skills. It seems that certain outcomes will not be the same in either case. The result is that the infrequent usage of a modest lab actually appears to be detrimental to the communication aspects of the language learning process. However, it is highly recommended to use language labs in teaching English for all educational levels. As Saudi Arabia is considered one of the wealthiest country, it is easy to build and improve using language labs in schools and colleges. There is always scope for improvement and advancement in any field and for any subject. It has to be accomplished with commitment and enthusiasm. Teachers are habituated to the traditional teaching methods. It is high time that their teaching methods have to undergo a change. Unless the new technology is adopted in English language teaching, they can not impart language skills in our learners at the rate of growing competition. According to this view, these are a few of the whole of those techniques that can be used to improve language skills through technology in the present generation. It can be implemented for a learner of any age at any stage. It will be more effective if technology is introduced from the elementary level. Accordingly, comprehensive language learning is possible through both classroom and language lab teaching, as applied for science subjects.

\section{Acknowledgments}

The researcher would like to send his gratitude and thanks to all of Albaha University personnel and staff members for their helpful and kind supports. The author also thanks all those who help him accomplish this manuscript.

\section{References}

Aikens, H. F., \& Ross, A. J. (1977). Immediate, repetitive playback/record-a practical solution. NAALD Journal, 11(2), 40-46.

Bagster-Collins, E.W., (1930). Studies in Modern Language teaching. New York: Macmillan.

Buchanan, M. A., \& MacPhee, E. D. (1928). An annotated bibliography of Modern Language methodology. Toronto, Canada: University of Toronto Press.

Carroll, J. B. (1962). A primer of programmed instruction in foreign language teaching. Heidelberg: Julius Groos Verlag.

Cornfield, R. R. (1966). Foreign language instruction: Dimensions and horizons. New York: Appelton-Century-Crofts. 
Delcolque, P., Annan, N., \& Bramoull'e, A. (2000). The history of computer assisted language learning web exposition. Retrieved May 15, 2016, from http://www.history-of-call.org/

Derthick, L. G. (1959). The purpose and legislative history of the foreign language titles in the National Defense Education Act, 1958. Publications of the Modern Language Association, 74, 48-51. https://doi.org/10.2307/2699220

Diekhoff, J. S. (1965). NDEA and modern foreign languages. New York: Modern Language Association.

Dodge, J. W. (1968). Language laboratories. In E. M. Birkmaier (Ed.), Britannica review of foreign language education (Vol. 1, pp. 331- 335). Chicago, IL: Encyclopaedia Britannica.

Godfrey, E. P. (1967). The state of audiovisual technology: 1961-1966. Washington DC: Department of Audiovisual Instruction, National Education Association.

Ek, J. D. (1974). Grant fever. NALLD Journal, 9(1), 17-23.

Grittner, F. (1969). Teaching foreign languages. New York: Harper \& Row.

Hmoud, SNA Al (2014). The Effectiveness of using English Lab on English Language Students' Pronunciation. Journal of Scientific Research, 1, 84-94.

Hocking, E. (1967). Language laboratory and language learning (2nd ed.) Washington, DC: Division of Audiovisual Instruction, National Education Association.

Keck, M. E. B., \& Smith, W. F. (1972). A selective, annotated bibliography for the language laboratory, 1959-1971. New York: ERIC Clearinghouse on Languages and Linguistics.

Léon, P. R. (1962). Laboratoire de langues et correction phonétique. Paris: Didier.

Lundi. (2010). Use of English Languge Lab in English Language Learning/Teaching. Retrieved from http://www.edutic.edunet.tn/labo/index.php/anglais/19-newseng/104-use-of-language-lab-in-english-langua ge-learningteaching

Marty, F. (1956). Language laboratory techniques. Educational Screen, 35, 52-53.

Scinicariello, S. (1997). Uniting teachers, learners, and machines: Language laboratories and other choices. In M. Bush, \& R. Terry (Eds.), Technology-enhanced language learning (pp. 185-213). Lincolnwood, IL: National Textbook Co.

Roby, W. B. (2004). Technology in the service of foreign language teaching: The case of the language laboratory. In D. Jonassen (Ed.), Handbook of Research on Educational Communications and Technology, (pp. 523-541, 2nd ed).

Peterson, P. (1974). Origins of the language laboratory. NALLD Journal, 8(4), 5-17.

Parker, W. R. (1960). Foreword. In E. J. Oinas (Ed.), Language teaching today (pp. v-viii). Bloomington, IN: Indiana University Research Center in Anthropology, Folklore, and Linguistics.

Parker, W. R. (1961). The national interest and foreign languages (3rd ed.) Washington, DC: U.S. Department of State.

Saettler, P. (1990). The evolution of American educational technology. Englewood, CO: Libraries Unlimited, pp. 187.

Slobin, D. (1985). Cross-linguistic evidence for the language-making capacity. In D. Slobin (Ed.), The Cross Linguistic Study of Language Acquisition (vol. 2: Theoretical Issues). Hillsdale, NJ: Erlbaum. 


\section{Appendixes}

\section{Appendix 1}

The frequencies of the pretest marks of the subjects in all English components

\begin{tabular}{|c|c|c|c|c|c|c|c|}
\hline \multicolumn{2}{|l|}{ Marks } & Listening & Speaking & Reading & Writing & Grammar & Vocab. \\
\hline \multicolumn{2}{|l|}{5} & 1 & 2 & 3 & 1 & 4 & 3 \\
\hline \multicolumn{2}{|l|}{4} & 5 & 6 & 7 & 7 & 7 & 6 \\
\hline \multicolumn{2}{|l|}{3} & 7 & 8 & 7 & 10 & 8 & 8 \\
\hline \multirow{2}{*}{ Passed } & $\sum$ & 14 & 16 & 17 & 18 & 19 & 17 \\
\hline & $\%$ & $54.3 \%$ & $57.8 \%$ & $60.7 \%$ & $63.6 \%$ & $66.2 \%$ & $61.5 \%$ \\
\hline \multicolumn{2}{|l|}{2} & 7 & 5 & 5 & 5 & 4 & 3 \\
\hline \multicolumn{2}{|l|}{1} & 6 & 4 & 4 & 4 & 2 & 5 \\
\hline \multicolumn{2}{|l|}{$\mathbf{0}$} & 0 & 2 & 2 & 3 & 5 & 4 \\
\hline \multirow[b]{2}{*}{ Failed } & $\sum$ & 13 & 11 & 11 & 12 & 11 & 12 \\
\hline & $\%$ & $45.7 \%$ & $42.2 \%$ & $39.3 \%$ & $36.4 \%$ & $33.8 \%$ & $38.5 \%$ \\
\hline
\end{tabular}

\section{Appendix 2}

The frequencies of the post-test marks of the subjects in all English components

\begin{tabular}{|c|c|c|c|c|c|c|c|}
\hline \multicolumn{2}{|l|}{ Marks } & Listening & Speaking & Reading & Writing & Grammar & Vocab. \\
\hline \multicolumn{2}{|l|}{5} & 5 & 7 & 4 & 3 & 8 & 5 \\
\hline \multicolumn{2}{|l|}{4} & 12 & 12 & 10 & 13 & 13 & 10 \\
\hline \multicolumn{2}{|l|}{3} & 6 & 4 & 6 & 7 & 4 & 9 \\
\hline \multirow[t]{2}{*}{ Passed } & $\sum$ & 26 & 23 & 22 & 23 & 25 & 24 \\
\hline & $\%$ & $96.26 \%$ & $85.18 \%$ & $81.48 \%$ & $85.18 \%$ & $92.59 \%$ & $88.89 \%$ \\
\hline \multicolumn{2}{|l|}{2} & 1 & 2 & 5 & 3 & 2 & 2 \\
\hline \multicolumn{2}{|l|}{1} & 0 & 1 & 1 & 1 & 0 & 0 \\
\hline \multicolumn{2}{|l|}{$\mathbf{0}$} & 0 & 1 & 2 & 1 & 0 & 1 \\
\hline \multirow[b]{2}{*}{ Failed } & $\sum$ & 1 & 4 & 5 & 4 & 2 & 3 \\
\hline & $\%$ & $3.74 \%$ & $14.82 \%$ & $8.52 \%$ & $14.82 \%$ & $7.41 \%$ & $11.11 \%$ \\
\hline
\end{tabular}

\section{Copyrights}

Copyright for this article is retained by the author(s), with first publication rights granted to the journal.

This is an open-access article distributed under the terms and conditions of the Creative Commons Attribution license (http://creativecommons.org/licenses/by/4.0/). 